DOI https://doi.org/10.18551/rjoas.2016-11.09

\title{
TRADE PRINCIPLES AND SHARIA-ADHERENCE BANKING PERFORMANCE ANALYSIS BY EMPLOYING MAQASID ISLAMIC SHARIA INDEX APPROACH: STUDY ON INDONESIAN SHARIA BANK
}

\author{
Wahyuniati Hamid* \\ Faculty of Economics and Business, University of Halu Oleo, Indonesia \\ Salim Ubud, Djumahir D., Aisjah Siti \\ Faculty of Economics and Business, University of Brawijaya, Indonesia \\ *E-mail: wahyuniatihamid@gmail.com
}

\begin{abstract}
This research is performed in order to empirically analyze and demonstrate trade principles and Islamic syariah (sharia) adherence-based banking performance by employing maqasid sharia index. This research is an explanatory research that aims to explain the causal relationship between variables using a quantitative approach. The study's population is eight Islamic banks based on data used in this study. Study period lasted from 2010 to 2014 . The analysis method used to answer hypothesis proposed in this study is PLS. The results of this study exhibits that trade principles possesses no significant effect on the performance of Islamic banking, trade principles possesses a significant effect on sharia adherence, and forementioned adherence has a significant effect on the sharia banking performance.
\end{abstract}

\section{KEY WORDS}

Trading principle, Sharia adherence, Maqasid Sharia Index.

Sharia economic and business development grows rapidly in recent years, especially in Indonesia. This phenomenon is exhibited through establishment of several sharia (Islamiclaw based) institutions, such as sharia banking, sharia insurance, sharia capital markets, sharia reksa dana (mutual funds), Baitul Mal wat Tamwil (Micro Financial Institution), sharia Union, sharia pawnshop etc. Sharia based business and economic activity are not only performed by mentioned institution above/ It also covers the various aspects, such as macro and micro economic and other economic problems.

The concept of sharia banks first appeared in the 1940s. The first established Islamic Sharia bank was MYT-Ghamr Bank founded in Egypt on 1963. Subsequently in 1971, Egypt established Islamic bank under the name of Nasser Social Bank. The first private Islamic Sharia bank that operates in the world is the Dubai Islamic Bank,which was established in Dubai on 1975 by a group of Muslim businessmen hailed from various countries. In the same year Kuwait government set up Kuwait Finance House. Ministers of Foreign Affairs who represents their respective countries as member of the Islamic Conference Organization.in Karachi Pakistan December 1970, Egypt submitted a proposal in the form of a study on the establishment of Islamic Banks International for the purpose of trading and development (International Islamic Bank for Trade and Development) and proposals for the establishment of a federation of sharia banks (Federation of Islamic Bank). Finally, the International Islamic bank was formally established on October 20, 1975 in Jeddah by name of the Islamic Development Bank (IDB).

The practice of sharia banking in Indonesia begins with the establishment of the first sharia bank in Indonesia, Bank Muamalat Indonesia in 1992. At that time, sharia banks have no strong legal backing due to lack of legislation specifically laws governing sharia banking. Sharia banking operated under the Act - Law No. 71992 on Banking. After Law No. 71992 on Banking was amended by Law No. 10 1998, which explicitly mentioned the establishment of the bank based on sharia principles and the possibility of conventional banks to establish sharia business units. Since then Indonesia adheres to dual banking system, which are 
conventional and sharia banking system. In the end, the existence of sharia banking is increasingly embraced after the enactment of Law No. 21 of 1998 concerning Islamic Sharia banking. Sharia banking in Indonesia has been strengthened and is expected to encourage further developments in Indonesia.

Sharia banks developed as financial institution, which conducts its operations by adhering the basic principles in Islamic economics. The purpose of Islamic economics contained in Sharia banks not only focuses on commercial purposes by achieving maximum profit alone, but also to consider its role in community welfare.

Based on Islamic Banking Statistics January (Data Statistik Perbankan Syariah) 2012 Bank Indonesia taken from http://www.bi.go.id, it is indicated that that the growth of sharia banking in Indonesia reached $40.2 \%$ per year in the last 5 years, far exceeding the growth rate of national banking industry which ranges from $20 \%$ per year. In addition, Indonesian sharia bank network possess 11 Sharia Banks (BUS), 24 Unit Usaha Syariah (UUS), and 156 Bank Pembiayaan Rakyat Syariah (BPRS), with 2,267 units of office networks spread across 33 provinces in Indonesia. Sharia banking is progressing very rapidly every year but the market share is still far below conventional banks' market share. Indonesia has large amount of Muslim population in the world, which makes it possessing great potential in gaining market share.

By attaching "Syariah», it means that sharia banks will carry out the mandate to run its business in strict adherence to sharia principles and regulations (Archer et al, 1998). Sharia principles are universal rules which application is not merely limited to certain regions. Sharia banks are expected to meet the criteria of 'adl (fairness), amanah (trustworthy), and ihsan (virtue and excellence), (Beekun and Badawi, 2005). Promoting justice and prosperity for the people and seek blessings from Allah (Hassan and Harahap, 2010 ). Upholding social goals, promoting Islamic values to employees, customers and the general public, as well as contributing significantly to the public welfare with sustainable development and poverty alleviation (Dusuki, 2008).

There are two (2) main activities in the sharia banking operations, those are fundraising (funding) and financing. Financing products available in shariah banks are as follows: savings, giro, and deposit. On the other hands, financing products of Islamic Sharia banking are: financing based on margin trading principle (murabaha), financing based on trading principle with payment in advance (salam), financing based on commission trade principle (istishna), financing based on lease trade principle (ljara), partnerships (musharaka) and equity (mudaraba). In addition, Islamic Sharia banking also provides services, which include: debts (hawalah), devolution / pawning (rahn), loan (qardh), representative (wakalah), assurance (wakalah), Guarantee (kafalah), and deposit (wadiah).

Sharia banks are required to adopt transparency, disclosure and documentation better compared to conventional banks. The lack of transparency in murabaha (margin trading) transactions, which sharia banks are required to provide all the details of the cost / price and transactions payment options should be in accordance to sharia teaching. Although sharia banks are currently growing in this country, but in practice it appears to plagiarize conventional banks' riba principles, which recently changed its linguistic discourse into Arabic. Ironically, there are reports of sharia fraud in the field.

According to Adnan Al-Bahar (Chairman of International Investors, an Islamic bank based in Kuwait), Islamic banking will become more responsible in the management of savings and deposits up to $5 \%$ within five or ten years into the future in the Islamic world.

One important aspect in the development of Islamic banks is sharia adherence. This is what differentiates sharia banks with conventional banks. To ensure Islamic principles are applied in banking institutions, the Sharia Supervisory Board or Dewan Pengawas Syariah (DPS) does the necessary supervision. In Bank Indonesia study, it is stated that customers who peruse sharia bank services, some have a tendency to stop being customers, among others due to doubts about the Islamic principles application consistency. The customer often questions adherence and conformity to sharia principles. Implicitly it exhibits that the practice of Islamic Sharia banking has not paid adequate attention to the Sharia principles. 
Sharia adherence in this context has three categories: 1) Understanding the commerce finances management practices to prevent Riba (charged interest) and Gharar (risk) element, 2) has a social purpose in Islamic context as well as offering social activities to people's lives, 3) establish and promote an integrated system of Islamic finance (Wafik Grais and Mateo Pellegrini, 2006). Thus it would be able to provide maximum welfare for stakeholders as management partner for commercial Islamic banking.

Research conducted by Shafi'i et al (2004) found empirical evidence of low amount of disclosure practices in financial reports, which adhere to sharia principles in Islamic Sharia bank in Indonesia. Annunciator confidence in accountants and managers of Islamic banks on sharia adherence disclosure practices as an adherence to sharia principles in Islamic banks is low.

Each muamalah or economic activity must be executed in accordance with sharia values and principles. One way to understand sharia is by understanding its objetives (Maqasid al-Sharia or five foundational goals of Sharia) which will provide the flexibility, dynamism and creativity in creating policies and activities of social life. Imam Ghozali, a highly respected Islamic scholar, defined sharia objectives as follows (Chapra, 2011, Dusuki, 2007):

Maqasid (purpose) sharia implementation done by sharia banking has become a concern for some sharia economic researchers although the numbers are still limited. Mustafa, O.M (2008) through his research has made performance measurement of Maqasid sharia banking in the form Maqasid Shariah Index or Syariah Maqasid Index (SMI). Maqasid sharia measured in this study is based on the concept of maqasid sharia described by Muhammad Abu Zahrah (1958) in his book «Usul Figh» explaining the concept of maqasid syariah (purpose of sharia) broadly and generally. There are three objectives of the existence of Islamic law, namely: Tahzib al -Fardi (Educating human beings), lqamah Al adl (Enforcing justice), and Jalb Maslahah (public interest) as measured by several parameters based on the three aspects.

Regarding problems associated with sharia based economic and business, so that developments remain in line with the sharia principles. According to Agustianto, sharia involvement in economic is important, such as providing financial solutions for economic problems that arise in both micro and macro scale, designing akad-akad (value) of sharia according to the needs of business products in various Islamic Sharia business institution, oversee and guarantee the entire banking products and financial sharia banks are executed according to sharia. Therefore, it is important for maqashid syari'ah al-syabity (Islamic laws written by God and His Apostles for the purpose of mankind prosperity) values are used as theoretical studies in stidying recent issues of sharia economics and business, in assuring economy in society shariah adherence and maqasid syariah as expected by mankind.

The results of this study are expected to provide benefits theoretically, in the form of contributions to the development of Financial Management Sciences, especially in the areas of banking, which are described as follows:

1. Strengthen and develop understanding of previous research which involves Sharia banking using maqasid syariah approach by Abu Zahra (1958);

2. Strengthen and develop understanding of previous research which involves sharia adherence;

3. Strengthen and develop understanding of previous research which involves trading principle.

Practical benefits appeared in the form of contributions to the government and the community, in this case the policies in sharia banking in particular on financial performance utilizing maqasid syariah approach and sharia adherence in sharia banking products. The results of this research provide benefits to investors in performing analysis and decision making for appropriate and profitable investments. 


\section{LITERATURE REVIEW}

Islamic Sharia Bank Definition. Indonesian Banking Act No. 71992 concerning banking was amended by Act No. 101998 to distinguish the bank activities into two, namely bank conducting conventional business and bank conducting business based on Islamic Sharia principles. Regarding specific specification on Islamic Banking is mentioned in Act No. 21 2008.

Pertaatmaja and Antonio (1992) explained that, «Islamic Bank is a bank that operates in accordance with sharia principles, namely banks ordinances refer to the operation based on Qur'an (Koran or Islamic Holy Text) and Hadith (Prophet Mohammad's sayings). It can also be interpreted as a bank which operations follow Islamic Shariah principles, especially concerning the Islamic mualamat (relation with people) procedures. Banks operating based on Islamic Sharia principles is encouraged to shun riba (charged interest) practices, which contain activities based on profit sharing investment and trade financing.

Maqasid Syariah. Maqasid word is plural form of maqsad (goal) in its linguistic nature. It meants 'intent to bring forth' (دصق) which stemmed from masdar punca (source), sasaran (goals), kelurusan (straightness), keadilan (fairness) and kesederhanaan (modesty). In other words, this term refers to the intent or objectives that brings its essence based on fact.

Sheikh Ibn 'Ashur $(1393 \mathrm{H})$ defines the maqasid' ammah (act of maintaining regulation) as the insights and wisdom emphasized in major part of Islamic legislation as opposed to be devoted into certain laws. Sheikh Ibn Assyria mentioned and explained maqasid 'ammah could be refered as act of maintaining regulations, attract kindness, resisting evil, treating every human being in fairness, respect sharia, reinforce faith and so on.

Al-Ghazali proposed maqshid al-Shari'ah (purpose of Sharia) theory by limiting sharia maintenance on five main elements, which are: religion, soul, mind, honor, and property. Similar statement was written by al-Syatibi that mashlahah is maintaining five main aspects, namely religion, life, intellect, lineage and property. Five elements above is considered sacred, noble and honored that must be protected and maintained. Maqashid alsyari'ah is also the general principles of Shariah (Kulliyat al-shari'a) which not only abstracted from elements of the shariah principles or from most of the arguments and Quran (Koran) and alSunnah (habit). Such conclusions seemed to be convincingly acceptable. The idea was put forward in the fifth century, in the era of the shariah principle, particularly al-Sunnah has been well documented, so there is a possibility for al-Sunnah to be scattered. Although it did not rule out the existence of an additional element to the fifth maqashid (goal) above, but the fifth is hard to be disregarded as an important element maqashid al-shari'ah (purpose of sharia).

Sharia Adherence. In general, the basic concept of the adherence serves as implementation and management of adherence risks in coordination with units working in risk management. The adherence function perform preventive supervisory duties and becomes an important element in the management and operations of Islamic banks, capital markets, sharia insurance, sharia pawnshops as well as non-bank sharia financial institution (sharia financial services union). This is done to ensure that policies, regulations, systems and procedures carried out by Islamic banking complies with the rules and regulations of Bank Indonesia, the Government, Bapepam-LK, MUI Fatwa, and law established based on international standard such as: IFSB, AAOIFI, Sharia Supervisory Board (SSB). Sharia adherence is part of risk management framework implement, and embodies a culture of adherence in managing the risk of Islamic banking. Sharia adherence follows international standards which are formulated and established by Islamic Financial Services Board (IFSB) in which the sharia adherence is part of the corporate governance. Sharia adherence is a manifestation of the fulfillment of all Islamic principles in an institution that has a characteristic form, integrity and credibility in Islamic banks. Adherence culture lies in the values, behaviors and actions which support the creation of Islamic banks om adherence Bank Indonesia regulations. Sharia Supervisory Board Dewan Pengawas Syariah (DPS) possesses authority for supervising Sharia adherence and delegates supervisory tasks given by the commissioner. Sharia adherence is increasingly important due to demand from customers to be innovative and business-oriented in offering instruments and new products 
as well as to ensure adherence with Islamic principles. Sharia Supervisory Board which members are sharia experts overseeing the activities and operations of financial institutions to ensure adherence towards sharia principles. Sharia Council was delegated a great responsibility and function as part of stakeholders, since they are the protector of the rights of investors and entrepreneurs who put their faith and trust in financial institutions. The existence of sharia supervisory board has five issues of corporate governance, which is independent, confidentiality, competence, consistency and transparency. Various arrangements in legislation or regulation has been established as regulatory development of Islamic banking in Indonesia, such as Act No. 212008 concerning sharia banking, which is more assertive and integrative set of sharia banking in Indonesia. In particular, the legal framework for sharia adherence has also been established by Bank Indonesia, through Bank Indonesia Regulation Number 13/2 / PBI / 2011 concerning the Implementation of Adherence Function Commercial Bank was set on January 12, 2011 and is valid from September 1, 2011.

Wafik Grais and Mateo Pellegrini, (2006), Sharia adherence in this context has three (3) categories: 1) Understanding the practice of management commerce finances to prevent Riba (charged interest) and Gharar (uncertainty or risk) elements, 2) has a social purpose in Islam as well as offering social community life activities, 3) establish and promote an integrated system of Islamic finance. Thus it would be able to provide maximum humility for stakeholders as partners managing commercial Islamic banking.

Sharia Bank Trading Principle. In sharia banking there are various activities which include: fund raising, fund distribution, buying, selling, and risk guarantee and other activities. Trading principle is implemented through the goods ownership transfer (transfer of property). Bank profits level was determined in advance and become part of the price of the sold goods.

Approved Trading principle reflects the key principles of mutual agreement of all parties and fairness, with an emphasis on politeness, generosity, and honesty. Collective agreements can occur only if there is a will, honesty as opposed to coercion, fraud, and disbelieving. Fairness includes commands such as contract fulfillment (contract), appropriate scale and size, appropriate pricing, the nature and amount of work, wages and payments, honesty and sincerity.

Hanafi found that legal sales transaction requires the presence of the goods and acknowledgment towards it. Therefore it would negate ignorance and strife, and that the physical possession is not a condition that must exist in legitimate sales.

Karim (2008) states that murabaha (margin trade)is a trade transaction where a bank states their profit. Bank sale price is the purchase price from suppliers plus profit (margin). Salam (payment in avance) is trading non-existent goods. Goods delivered as payments are made in cash. In this transaction, quantity, quality, price and time of delivery of goods to be determined in presice. Istishna (commission trade) resembles salam products, but in istisnaa payment may be in installments through bank. Through trade channeled financing, Islamic banks will receive income in the form of a mark-up or profit margin. Islam does not tend to set prices or profit margins according to demand.

Trade in Arabic language consists of two words that implies the opposite, namely Al Bai 'which means sale and Ash Syira'a means buy. According to the legal terms of Syara (Path of Life), trading is the is property exchange (in a broad sense) on the basis of mutual will or exchange an object (item) is made between the two parties based on priorly established agreement (contract) specified on consensus (see Sura Az Zumar: 39, At Tawbah: 103, Hud: 93).

Review of Previous Researches. Research conducted by Murtiyani (2008), regarding sharia adherence index in Malaysian Islamic banks which is limited to Bai'al Inal (sale with immediate repurchase) products states that sharia adherence index at an Islamic banking has comprehensively formed two concepts. Those are annual financial statements and Bai'al inah trading concept. According to study's result, it exhibited index number of $54.54 \%$ Sharia Adherence Bai'al inah in an Islamic bank and does not fulfill regulations on sharia adherence which reached $45.46 \%$. Interpretation of sharia adherence for selling Bai'al-Inah in Islamic 
bank in Malaysia showed an index number between $26 \%$ to $55 \%$ in the «low»group which could be interpreted as "not adhering» values in Bai'al-Inah trading principle and sharia principle i established by AAOIF.

Research of Antonio, Sanrego, and Taufiq (2012), regarding the implementation of sharia bank performance analysis Maqasid (purpose) Index in Indonesia and Jordan. Using maqasid sharia (sharia purpose) index approach for measuring sharia banking performance, they discovered that the financial performance of sharia banking in Indonesia is different from banking in Jordania, because there is no publication of alms data from Jordania Islamic Bank (represented by JIB and IIAB).

Research conducted by Mahmood and Khatun (2013) examines the Adherence to AAOIFI Sharia Governance System: A study of Islamic banks in Bangladesh. The study examines adherence level of 17 private commercial bank in Bangladesh. The results exhibits that none of the Islamic bank fully comply to AAOIFI governance system because they do not have the governance and audit committees. The average adherence rate to the highest in AAOIFI Islamic bank was low and medium for Islamic banking that operate through multiple windows and branches. Therefore this study proposed that sharia adherence level should be enhanced by all banks. Moreover uniformity and transparency must be reported.

Conceptual Framework. This study involves the analysis trading principle and AlWadiah principle on sharia banking in Indonesia compared to sharia adherence and maqasid syariah performance. This descriptive research and case studies illustrate the ongoing processes at the time the research was conducted and investigate the cause of a particular phenomenon in detail regarding a particular object for a certain period with in depth thoroughly (Umar, 2003: 55 -56).

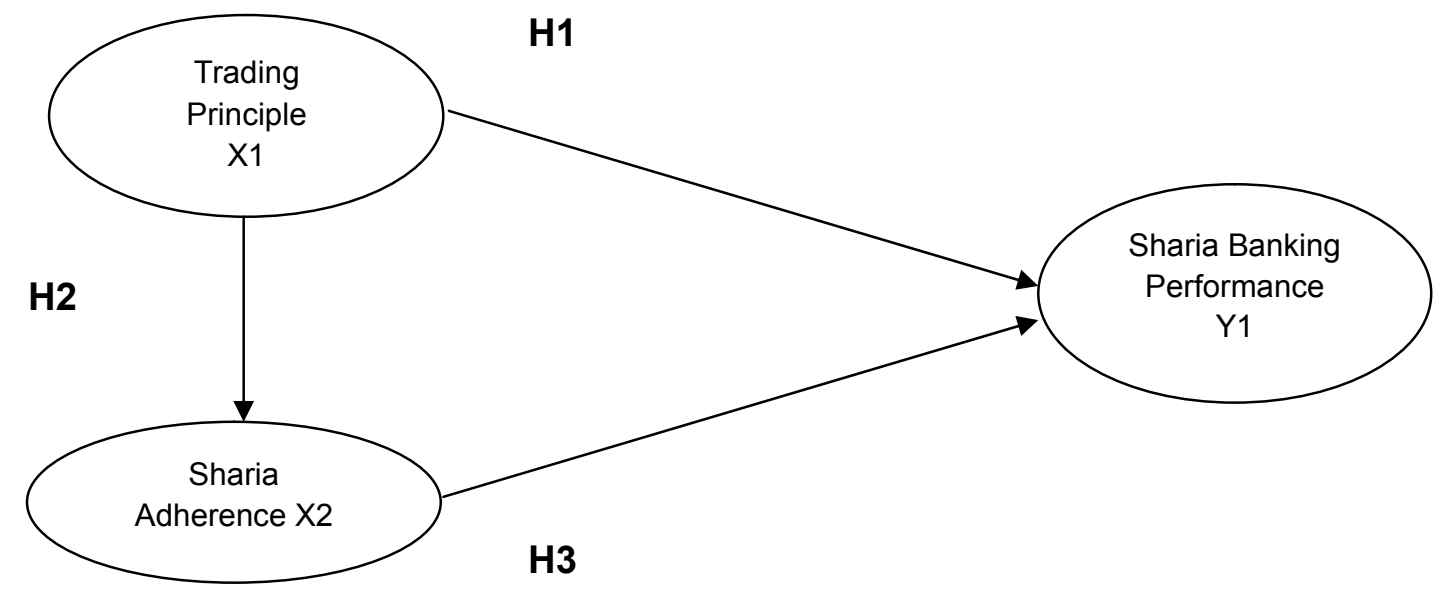

Figure 1 - Research Concept Framework

Hyphotheses:

- $\mathrm{H}_{1}$ : Relationship and influence of trading principles towards sharia banking performance;

- $\mathrm{H}_{2}$ : Relationship and influence of trading principles towards sharia adherence;

- $\mathrm{H}_{3}$ : Relationship and influence of Sharia adherence towards sharia banking performance.

\section{RESEARCH METHODS}

Research Approach. The approach used in this study is a positivist approach. The approach aims to answer the research problem through hypothesis testing analysis of the relationship between trading principle and sharia adherence on sharia banking using maqasid syariah index approach.

Research Object and Location. This research referred to each bank's official website and supplemented by data from Indonesian Bank and Informasi Lembaga Keuangan 
(Information on Financial Authority or IBIS). The object of this study was Islamic Sharia Banks or Bank Umum Syariah (BUS) in Indonesia.

Data Type and Source. The data used are secondary data, taken from annual financial report (Annual Report). Study period lasted from 2010 through 2014.

Population and Sample. This study was included in census study. According to Arikunto (1996: 115) population is the entirety of the study subjects. The study population was sharia banks in Indonesia, based on the data used in this study. The data used are secondary data, which are audited financial statements taken from annual financial report (Annual Report). Seven sharia banks taken as research objects are as follows:

1. Bank Muamalat Indonesia (BMI)

2. Bank Syariah Mandiri (BSM)

3. Bank Mega Syariah (BMS)

4. Bank Syariah Bukopin (BSB)

5. Bank Rakyat Indonesia Syariah (BRIS)

6. Bank Syariah BNI

7. BCA Syariah

Research Variable and Operational Variable Definition. This research is a descriptive research that describes the nature of ongoing processes at the time of the research and examine the causes of a particular symptom in detail about a particular object for a certain period with sufficient depth thoroughly (Umar, 2003: 55-56). The variables in this research are classified as follows:

1. Exogenous variables is known as independent variables. In this study, exogenous variables are; trading principle variables (X1), and sharia adherence (X2)

2. Endogenous variables, ie, variables that is predicted by one or more of other variables in the model. Endogenous variable is also known as the dependent variable. Endogenous variable in this study is represented by sharia banking performance (Y1).

Data Analysis. Data analysis employed in this study consisted of two types of analysis, which are: descriptive statistical analysis and inferential statistical analysis. Descriptive statistics analysis is utilized to provide an illustration or descriptive empiric for the data collected in the study (Ferdinand, 2006). This study used a descriptive statistical analysis in the form of average value.

Inferential statistical analysis is used to draw inferences from the sample to the population, and the analytical methods used are partial least square (PLS).

\section{FINDINGS AND DISCUSSION}

Effect of Trading Principles Towards Sharia Banking Performance. First hypothesis examines trade principle (X1) on sharia banking performance (Y1) which is exhibited as correlation coefficient of -0152 with a $(p)$ value of 0.295 . Therefore it is not significant. It can be concluded that the increase or decrease in funding distribution based on trading principle possessed no significant effect on sharia banking performance, so the first hypothesis proposed in this study cannot be accepted or cannot be supported by empirical facts.

Effect of Trading Principle Towards Sharia Adherence. Second hyphothesis examination is testing the trading principle influence (X1) on Sharia adherence (X2) which is exhibited as correlation coefficient of 0.644 with $(p)$ value of 0.000 . Therefore it has significant effect. It could be concluded that increase and decrease in funding distribution based trading principle proved to provide significant effect on sharia adherence. Therefore the second hypothesis proposed in this study can be received and supported by empirical facts.

Effect of Sharia Adherence Towards Sharia Banking Performance. Third hypothesis examination is testing influence of sharia adherence (X2) on the sharia banking performance $(Y 1)$ which is exhibited as correlation coefficient of 0.778 with $(p)$ value of 0.000 . Therefore it has significant effect. It could be concluded that increased sharia adherence has significant effect on the sharia banking performance; therefore fifth hypothesis proposed in this study 
can be accepted or can be supported by empirical facts. This indicates that the higher the level of sharia adherence will directly influence the performance of sharia banking.

\section{CONCLUSION}

Based on the findings, several conclusions can be drawn. Firstly, financing based on trade principle possess no significant effect on the performance of sharia banking. Secondly, funding is based on trading principle has a significant effect on sharia adherence. Finally, sharia adherence possesses significant effect on the sharia banking performance.

\section{SUGGESTION}

To further develop this research in the future, it is recommended to re-examine the consistency of the findings contained in this research by developing research methods, variable developments, research samples expansion and variable measurement as well as endeavor to assess the ethic and religion values in financial decision-making and investment in order to improve performance of Islamic Sharia banking.

\section{REFERENCES}

1. Antonio, M.S. 2001. Bank Syariah: Dari Teori ke Praktek. Jakarta: Gema Insani Press.

2. Antonio, M.S. and Sanrego, M.T. 2012. An Analysis of Islamic Banking Performance: Maqashid Index Implementation in Indonesia and Jordania.

3. Arikunto, S. 1996. Prosedur Penelitian: Sut Pendekatan Praktek. Jakarta. : PT. Rineka Cipta.

4. Bank Indonesia. 2002. Cetak Biru Pengembangan Perbankan Syariah. Jakarta: Direktorat Perbankan Syariah Bank Indonesia.

5. Bank Indonesia. 2012. Outlook Perbankan Syariah 2012. Jakarta: Direktorat Perbankan Syariah Bank Indonesia.

6. Bank Indonesia. 2011. Statistik Bank Indonesia September 2011. Jakarta: Bank Indonesia.(http://www.bi.go.id, diakses 9 Oktober 2011)

7. Chapra, M.U. 2005. Islam dan Pembangunan Ekonomi. Ikhwan Abidin,Translator. Depok: Gema Insani. from: Islam and Economic Development.

8. 2008. The Islamic Vision of Development in The Light of Maqasid al-Shariah. London: The International Institute of Islamic Thought.

9. 2009. Mari Kembali ke Maqasid Al-Shariah. Seminar Public Lecture on Islamic Economic And Business, Accessed December 5, 2011. http://majalahsharing.wordpress.com

10. Dusuki, A.W. 2012. Maqasid al Shariah, Maslahah, and Social Responsibility. The American Journal of Islamic Social Sciences, 24:1

11. Ebrahim, M.S. 2001. Islamic Banking in Brunei Darussalam.

12. Hameed, S. 2004. Alternative Disclosure and Performance Measures for Islamic Banks. Malasyia: IIUM.

13. Kuppusamy. 2010. Measurement of Islamic Banks Performance Using a Shariah Conformity and Profitablity Model. Jurnal Review of Islamic Economics, 13(2):35-48.

14. Karim, A.A. 2008. Bank Islam: Analisis Fiqih dan Keuangan Edisi 3. Jakarta: PT Raja Grafindo Persada.

15. Maya, P.P.P. 2009. Analisis Pembiayaan Mudharabah, Musyarakah, dan Murabahah Hubungannya dengan Profitabilitas Bank Umum Syariah Periode 2003-2007.. Unpubished Undergraduate Thesis. Jurusan Manajemen, Fakultas Ekonomi, Universitas Islam Negeri Malang.

16. Murtiyani. 2008. Indeks pematuhan syariah pada bank Islam di Malaysia. Produk Baial inal.

17. Mohammed, D. 2008. The Performance Measures of Islamic Banking Based on the Maqashid Framework. Paper of IIUM International Accounting Conference (INTAC IV) held at Putra Jaya Marroitt. 
18. Mohammed, M.O. and Taib, F.M. 2009. Testing The Performance Meaasured Based on Maqashid al-Shariah (PMMS) Model on 24 Selected Islamic and Conventional Banks. Malasyia: IIUM.

19. Mughess, S. 2008. The Recent Financial Growth of Islamic Banks and Their Fulfilment of Maqashid alShariah Gap Analysis. Malasyia: INCEIF.

20. Pertaatmaja, K. and Antonio, M.S. 1992. Apa dan Bagaimana Bank Islam. Yogyakarta: Dana Bhakti Wakaf.

21. Ridwan, M. 2005. Manajemen Baitul Maal Wa Tamwil (BMT). Yogyakarta: UII Press.

22. Rosly, S.A. 2010. Shariah Parameters Reconsidered. International Journal of Islamic and Middle Eastern Finance and Management 3 (2), :137

23. Salim, U. 2011. Manajemen Keuangan Strategik. Malang. UB Press.

24. Sanrego, Y.D. 2010. Indeks Untuk Bank Syariah. SHARING Inspirator Ekonomi \& Bisnis Syariah Edisi 41 Thn IV-Mei 2010. SESRIC. (2012). OIC Outlook Series Islamic Finance in OIC Member Countries May 2012. Turkey. Accessed July.7, 2012.

25. Stern, J.M. 2001. The EVA Challenge Implementing Value-Added Change in an Organization. New York: John Wiley \& Sons, Inc.

26. Umar, H. 2003. Metode Riset Bisnis. Jakarta: PT Gramedia Pustaka Utama.

27. Yuwono, S., Sukarno, E., and Ichsan, M. 2004. Petunjuk Praktis Penyusunan Balance Scorecard Menuju Organisasi yang Berfokus pada Strategi. Jakarta: PT Gramedia Pustaka Utama.

28. Yoon, K.P. and Hwang, C-L. 1995. Multiatribut Decision Making an Introduction, India: Sage Publications.

29. Zahrah, M.A. 1958. Ushul Al-Fiqh. Darul Fikri al-Araby. 